\title{
Perception of Complexity Area in Management-an Exploratory Study in Poland
}

\author{
Iwona Gorzeń-Mitka, Małgorzata Okręglicka \\ Czestochowa University of Technology, Poland \\ iwona.mitka@zim.pcz.pl
}

\begin{abstract}
The purpose of this article is presentation theoretical and empirical analysis about complexity perception in organization. We propose following thesis: "perception of complexity in company is possible by separating complexity levels of particular areas of company activity". Taking into account the general aspect of perception and complexity perception in management to the understanding this concept we use the Cynefin model. We accept the assumption that the recognition complexity levels in selected areas create value in decision making processes. Theoretical considerations are supplemented by results of the study in 157 Polish SMEs. The study was conducted in May 2015.
\end{abstract}

Keywords: Perception, complexity, complexity levels, SME, Cynefin model

\section{Introduction}

The issue of complexity from years is extensively discussed on the international level - nowadays also in the management literature. Academic literature and practice research indicate complexity approaches in many different areas e.g. computer science, psychology, projects and other. The difficulty stems from defining and consequently the understanding of complexity. Complexity can be understood in different ways, not only in different fields but also has different connotations within the same field. But how indicate authors in yours earlier work, we observe in management literature the duality of the perception of contemporary organizations: on one side - the quest for clarity, certainty, predictability and control, on the other - the unavoidably ambiguous and paradoxical, uncertain, unpredictable and complex dynamics of organizations (Gorzeń-Mitka et al., 2015). One of most universal approach to decision making in complexity view is Cynefin model. The Cynefin model shows a new perspective of looking at a decision making system in organizations. In academic literature we can find many areas which used this approach. According to McLeod \& Childs (2013) the ease of using this model, together with its innovativeness, makes it „a kind of guidance for managers on their thoughts and actions". The model shows a new perspective of looking at various situations and indicates what actions should be taken as response to various situations. For that reason, it is more and more often and willingly used in business practice (analysis of G.W.Bush administration's policy (O'Neill, 2004), analysis of the supply chain (Shepherd et al., 2006) and qualitative data (McLeod and Childs, 2013). Detailed discussion about Cynefin model is presented by authors in "Improving Decision Making in Complexity Environment" (Gorzeń-Mitka \& Okręglicka, 2014).

Based on Cynefin model we propose following thesis: "perception of complexity in company is possible by separating complexity levels of particular areas of company activity". We accept the assumption that the recognition complexity levels in selected areas create value in decision making processes. The article is structured as follow. The next section provides the theoretical background about a few aspects of complexity perception understanding in academic management literature. Next will be presented basic assumption of complexity model - Cynefin and explain the development of the hypothesis. The next section of the paper provides some empirical evidence on complexity perception in the light Cynefin model (we discussed in this section data and methodology including a detailed description of the measures used in the empirical analysis). The "Results" section presents the empirical findings, and the final section concludes.

\section{Literature Review}

Perception of Complexity: Perception is being defined as the act or faculty of apprehending by means of the senses or of the mind. Accordingly, it is associated with understanding or cognition (Wieczorek-Kosmala, Gorzeń-Mitka, 2013). With regard to this definition, the perception of complexity is two-dimensional. The 
first dimension addresses the understanding of complexity, while the second one - the cognition of complexity embodied in the entity's ability to analyze complexity. Complexity derives from the Latin com: together, plectere: to weave. The adjective 'not easily analyzed was first recorded in 1715. Thus, from its first usage, complexity was synonymous with the ease of understanding something. The essence of complexity is interdependence. Interdependence implies that reduction by decomposition can't work because the behavior of each component depends on the behaviors of the others. Complexity is accompanying many type of the business decisions increasingly. Complexity is also in focus as a subject of theoretical and empirical academic studies often. Researchers recommends for business entities to take actions including complexity with the purpose to enhance the value creation process (Lemańska-Majdzik, 2009). Complexity has been widely researched in the science literature, nowadays also in the management literature. Complexity and the way to deal with its increasing in the company itself and its environment has become a key competitive factor.

Complexity has turned out to be very difficult to define. The debate regarding complexity is complicated even more because some authors claim their own definition of complexity. Different authors have different perceptions on how they define different synonyms word of complexity. In increasingly discussion on complexity management important view is shown for example by Faisal et al. (2012). In their view complexity management is a business approach encompassing investigation, evaluation and optimization of complexity within organizations. Because complexity has an impact on the value chains within the business processes, it is important for management to have a holistic approach to complexity in the organization. SME is the category of companies particularly exposed to the impact of risk factors and complexity of the environment. The diagnosis of their awareness of the factors determining the efficiency of activities in the field of complexity perception and management seems to be a legitimate (Sipa, 2013; Skibiński, 2014). This paper aims at supporting the thesis, that complexity on the business entities' can be perceived through the different levels of complexity as an element of management complexity process. In particular, it aims at discussing some theoretical and practical aspects that allow a better understanding of complexity perception.

Complexity in Management According Cynefin Model: One of models that explains and supports complex decision making processes in the choice of a strategy for action is Cynefin. How Snowden (2002), the Cynefin framework indicate advocates the use of narrative for understanding complexity and emphasizes the social aspects of sense making while taking into account various environmental circumstances. This framework suggests four basic approaches to strategic decision-making, depending on the level of contextual uncertainty. Additionally, it indicates good practices which, according to the idea of Cynefin, should be tailored to the individual specificity of the situation in which a given organization finds itself. In practice, the model can be used as a tool supporting project, team and organization management, and even for analyzing international problems (Snowden, 2010). The Cynefin model consists of five areas (domains) (Kurtz \& Snowden, 2003). The areas are:

- Simple - the relationship between cause and effect is obvious for everyone. The proposed action scheme: sense-categorize-respond. When taking the actions we can apply the best practices.

- Complicated - the relationship between cause and effect requires analysis or a different form of investigation and/or the application of expert knowledge. The proposed action scheme: senseanalyze-respond. When taking the actions we can apply the good practices.

- Complex - the relationship between cause and effect can be noticed only in retrospect; it cannot be predicted in advance. The proposed action scheme: probe-sense-respond. The effect of the actions taken can be a discovery of emergent practice.

- Chaotic - there is no relationship between cause and effect at systems level. The proposed action scheme: act-sense-respond. We can discover novel practice.

- Disorder - placed in the middle of the framework. D.SnowdeniM.E.Boone describes it as follows:

"The very nature of the fifth context-disorder-makes it particularly difficult to recognize when one is in it. Here, multiple perspectives jostle for prominence, factional leaders argue with one another, and cacophony rules. The way out of this realm is to break down the situation into constituent parts and assign each to one of the other four realms. Leaders can then make decisions and intervene in contextually appropriate ways" (Snowden \& Boone, 2007, p.73). The Cynefin model shows a new perspective of looking at a decision making system in organizations. Our research based on this concept.

This part of paper is prepared on earlier author's studies, where you can find more detailed discussion about Cynefin model (Gorzeń-Mitka \& Okręglicka, 2014). 


\section{Methodology}

Identification of perception of complexity in enterprise management processes was performed during the study which aimed to analyze complexity of business processes in small, medium and large enterprises in Poland. Purposive sample was used for the study. The study was conducted in the April and May of 2015 on a sample of 157 companies categorized, according to the number of employees, as small, medium and large enterprises. The survey questionnaire was addressed to both manufacturing, trade and service enterprises. The sample was not fully representative, thus the study should be regarded as a pilot project, to further explore the subject, and facilitate future research on representative samples. The main characteristics of the study sample are presented in Tables 1-3.

Table1: Cross table: Main area of activity* Company size

\begin{tabular}{|c|c|c|c|c|c|c|}
\hline & & & $\begin{array}{l}\text { Company size } \\
\text { Small (10-49) }\end{array}$ & $\begin{array}{l}\text { Medium } \\
(50-249)\end{array}$ & Large $(>250)$ & Total \\
\hline \multirow{10}{*}{ 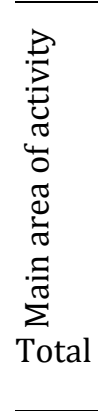 } & \multirow[t]{2}{*}{ production } & $\mathrm{N}$ & 15 & 3 & 5 & 23 \\
\hline & & $\%$ & $9.6 \%$ & $1.9 \%$ & $3.2 \%$ & $14.6 \%$ \\
\hline & \multirow[t]{2}{*}{ trade } & $\mathrm{N}$ & 76 & 6 & 6 & 88 \\
\hline & & $\%$ & $48.4 \%$ & $3.8 \%$ & $3.8 \%$ & $56.1 \%$ \\
\hline & \multirow[t]{2}{*}{ services } & $\mathrm{N}$ & 38 & 4 & 0 & 42 \\
\hline & & $\%$ & $24.2 \%$ & $2.5 \%$ & $.0 \%$ & $26.8 \%$ \\
\hline & \multirow[t]{4}{*}{ other } & $\mathrm{N}$ & 1 & 3 & 0 & 4 \\
\hline & & $\%$ & $.6 \%$ & $1.9 \%$ & $.0 \%$ & $2.5 \%$ \\
\hline & & $\mathrm{N}$ & 130 & 16 & 11 & 157 \\
\hline & & $\%$ & $82.8 \%$ & $10.2 \%$ & $7.0 \%$ & $100.0 \%$ \\
\hline
\end{tabular}

Source: own study

Small businesses employing between 10 and 49 workers dominated the sample, accounting for 82 , $8 \%$ of all surveyed companies. The second-largest group consisted of medium-sized enterprises, employing between 50 and 249 people, which accounted for $10,2 \%$ of all respondents. The largest group of companies, at 56, 1\%, have been operating in trade market, $26,8 \%$ - in service market and $14,6 \%$ - in production (Table 1 ).

Table 2: Cross table: Main area of activity * Number of years of operation in the market

\begin{tabular}{|c|c|c|c|c|c|c|c|}
\hline & & & \multicolumn{5}{|c|}{ Number of years of operation in the market } \\
\hline & & & $<1$ year & 1 - 5 years & 5 - 10 years & $>10$ years & Total \\
\hline \multirow{10}{*}{ 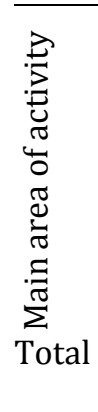 } & production & $\mathrm{N}$ & 1 & 3 & 5 & 14 & 23 \\
\hline & & $\%$ & $.6 \%$ & $1.9 \%$ & $3.2 \%$ & $8.9 \%$ & $14.6 \%$ \\
\hline & Trade & $\mathrm{N}$ & 3 & 28 & 28 & 29 & 88 \\
\hline & & $\%$ & $1.9 \%$ & $17.8 \%$ & $17.8 \%$ & $18.5 \%$ & $56.1 \%$ \\
\hline & Services & $\mathrm{N}$ & 2 & 11 & 12 & 17 & 42 \\
\hline & & $\%$ & $1.3 \%$ & $7.0 \%$ & $7.6 \%$ & $10.8 \%$ & $26.8 \%$ \\
\hline & Other & $\mathrm{N}$ & 0 & 0 & 0 & 4 & 4 \\
\hline & & $\%$ & $.0 \%$ & $.0 \%$ & $.0 \%$ & $2.5 \%$ & $2.5 \%$ \\
\hline & & $\mathrm{N}$ & 6 & 42 & 45 & 64 & 157 \\
\hline & & $\%$ & $3.8 \%$ & $26.8 \%$ & $28.7 \%$ & $40.8 \%$ & $100.0 \%$ \\
\hline
\end{tabular}

Source: own study 
Table 3: Cross table: Main area of activity * Respondent's position

\begin{tabular}{|c|c|c|c|c|c|c|c|c|c|}
\hline & & & $\begin{array}{l}\text { Respon } \\
\text { owner }\end{array}$ & $\begin{array}{l}\text { dent'sposition } \\
\text { senior manager }\end{array}$ & analyst & director & manager & other & Total \\
\hline \multirow{10}{*}{ 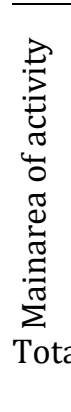 } & \multirow[t]{2}{*}{ production } & $\mathrm{N}$ & 14 & 1 & 0 & 2 & 6 & 0 & 23 \\
\hline & & $\%$ & $8.9 \%$ & $.6 \%$ & $.0 \%$ & $1.3 \%$ & $3.8 \%$ & $.0 \%$ & $14.6 \%$ \\
\hline & \multirow{2}{*}{ trade } & $\mathrm{N}$ & 59 & 3 & 1 & 13 & 8 & 4 & 88 \\
\hline & & $\%$ & $37.6 \%$ & $1.9 \%$ & $.6 \%$ & $8.3 \%$ & $5.1 \%$ & $2.5 \%$ & $56.1 \%$ \\
\hline & \multirow{2}{*}{ services } & $\mathrm{N}$ & 22 & 3 & 0 & 7 & 6 & 4 & 42 \\
\hline & & $\%$ & $14.0 \%$ & $1.9 \%$ & $.0 \%$ & $4.5 \%$ & $3.8 \%$ & $2.5 \%$ & $26.8 \%$ \\
\hline & \multirow{2}{*}{ other } & $\mathrm{N}$ & 2 & 0 & 0 & 0 & 1 & 1 & 4 \\
\hline & & $\%$ & $1.3 \%$ & $.0 \%$ & $.0 \%$ & $.0 \%$ & $.6 \%$ & $.6 \%$ & $2.5 \%$ \\
\hline & & $\mathrm{N}$ & 97 & 7 & 1 & 22 & 21 & 9 & 157 \\
\hline & & $\%$ & $61.8 \%$ & $4.5 \%$ & $.6 \%$ & $14.0 \%$ & $13.4 \%$ & $5.7 \%$ & $100.0 \%$ \\
\hline
\end{tabular}

Source: own study

The largest group of companies, at $40.8 \%$, has been operating in the market for more than 10 years, $28.7 \%$ of the businesses have been active for 5 to 10 years, and $26.8 \%$ of the businesses have been active for 1 to 5 years, with the rest of the respondents operating up to 1 years (Table 2). The following research problems were proposed, with the main aim of the project in mind:

P1 - How SMEs assess management complexity in their businesses?

P2 - Whether and how the complexity perception depends on company size or main business area?

P3 - What complexity level characterized by selected activity areas in company?

Statistical analysis of the survey results has allowed for a full or partial verification of the hypotheses. In this study is two control variables adopted. There is company size by number of employees and main field of activity. Based on received data, correlation coefficients have been calculated. For examining the level of complexity perception in selected areas of company activity Kendall tau rank correlation coefficients were used. Test probability $\mathrm{p}<0.05$ was considered as significant. The results were analyzed using the statistical application IBM SPSS ver. 19.

\section{Results}

This paper examines SMEs behavior by testing research problems related to SMEs complexity perception. These problems examine whether firm characteristics (size, main field of activity) that differ due complexity perception by levels. In testing these hypotheses we find several activity areas that are significantly related to obtaining a complexity perception in SMEs. This evidence is important for future research examining the firm's decision to influence complexity perception to decision making. The analysis of the complexity perception in SMEs began with the assessment of the level of knowledge of the respondents with respect to the complexity management (Table 4).

Table 4: Complexity perception due to company size and main area of activity (\%)

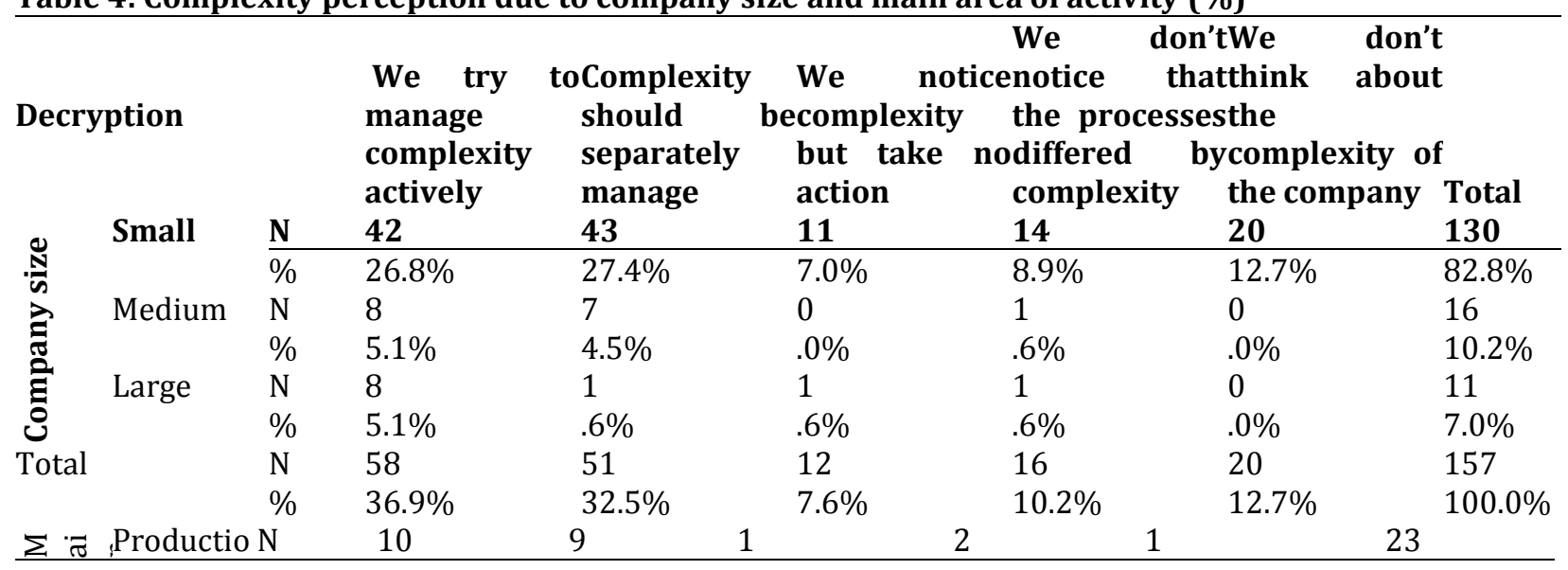




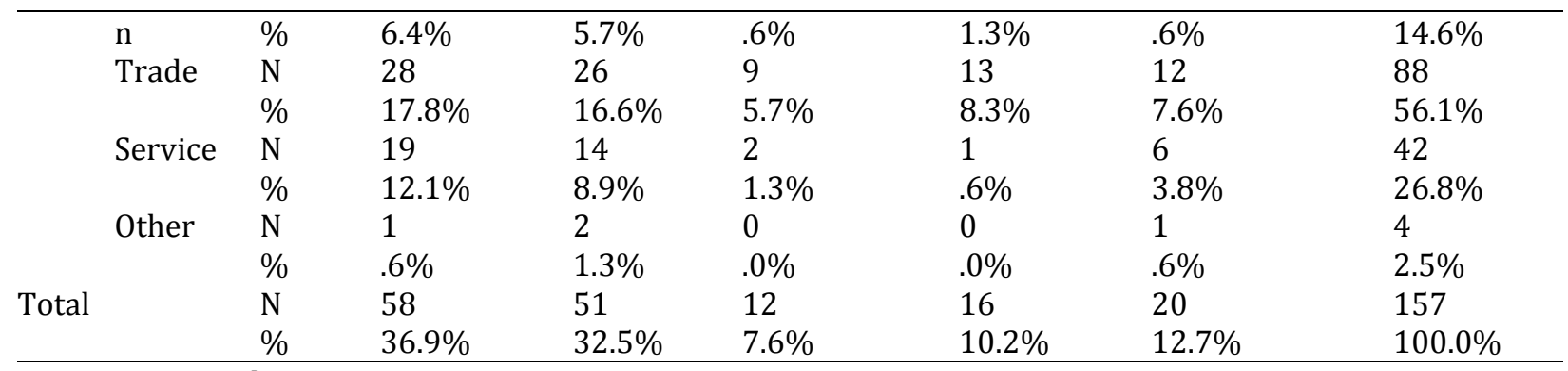

Source: own study

Respondents evaluated the perception of complexity in five categories (see Table 4). Analysis of the data presented in Table 4 allows drawing the following conclusions. Almost $40 \%$ of them reported a proactive approach to manage complexity. The leading group consisted of traders employing up to 50 employees. In their opinion complexity should be a separate management process. At the same time almost a quarter of respondents do not see the need to take action or thinking about the complexity of the processes undertaken by it in operational activities. Another area of analysis was the diagnosis of the respondents' knowledge on the complexity perception in selected particular areas of company activity (the study distinguishes between 14 processes). The results are shown in the table 5.

Table 5: Complexity perception by company characteristics $\mathrm{N}=157$

\begin{tabular}{|c|c|c|c|}
\hline \multicolumn{2}{|l|}{ Description } & \multirow{2}{*}{\multicolumn{2}{|c|}{$\begin{array}{lll}\begin{array}{l}\text { Company size by } \\
\text { number of employees }\end{array} & \begin{array}{l}\text { Main field of } \\
\text { activity }\end{array} \\
-0,097 & 0,032\end{array}$}} \\
\hline \multirow{2}{*}{ searching for new customers and new markets } & tau & & \\
\hline & $1-\mathrm{p}$ & 0,095 & 0,328 \\
\hline \multirow{2}{*}{$\begin{array}{l}\text { increasing investment in promotion and } \\
\text { advertising }\end{array}$} & tau & $-0,107$ & 0,157 \\
\hline & $1-p$ & 0,070 & 0,013 \\
\hline \multirow{2}{*}{ creating new products and services } & tau & $-0,009$ & $-0,101$ \\
\hline & $1-p$ & 0,448 & 0,074 \\
\hline \multirow{2}{*}{ co-operation with business organizations } & tau & $-0,014$ & 0,088 \\
\hline & $1-p$ & 0,423 & 0,104 \\
\hline \multirow{2}{*}{ improvement of existing products and services } & tau & $-0,030$ & $-0,099$ \\
\hline & $1-p$ & 0,341 & 0,079 \\
\hline \multirow{2}{*}{ purchase of new machines and devices } & tau & 0,078 & $-0,184$ \\
\hline & $1-p$ & 0,142 & 0,005 \\
\hline \multirow{2}{*}{$\begin{array}{l}\text { improvement of quality of products, services and } \\
\text { manufacturing }\end{array}$} & tau & 0,014 & $-0,099$ \\
\hline & $1-p$ & 0,422 & 0,081 \\
\hline \multirow{2}{*}{ employment of newworkers } & tau & $-0,135$ & 0,048 \\
\hline & $1-p$ & 0,030 & 0,246 \\
\hline \multirow{2}{*}{ introducing IT to manage the company } & tau & 0,119 & 0,028 \\
\hline & $1-\mathrm{p}$ & 0,047 & 0,340 \\
\hline \multirow{2}{*}{ upgrading skills and qualifications of employees } & tau & $-0,071$ & 0,121 \\
\hline & $1-\mathrm{p}$ & 0,169 & 0,046 \\
\hline \multirow{2}{*}{ market research } & tau & $-0,002$ & $-0,021$ \\
\hline & $1-p$ & 0,488 & 0,381 \\
\hline \multirow{2}{*}{ understanding and connecting with other entities } & tau & 0,071 & 0,084 \\
\hline & $1-\mathrm{p}$ & 0,163 & 0,116 \\
\hline \multirow{2}{*}{ searching for investors and business partners } & tau & $-0,028$ & 0,122 \\
\hline & $1-p$ & 0,350 & 0,040 \\
\hline \multirow{2}{*}{ acquisition of EU funds } & tau & 0,040 & 0,012 \\
\hline & $1-p$ & 0,286 & 0,433 \\
\hline \multirow{2}{*}{ changes in the scope of business or sector } & tau & 0,103 & 0,074 \\
\hline & $1-p$ & 0,084 & 0,153 \\
\hline
\end{tabular}

${ }^{*}$ Correlation is significant at the 0.05 level (one-sided).

Source: own study 
The survey shows how respondents assess their complexity perception in relation to company size. Two of the selected activities of the superior were found out to be statistically significant $(p<0.05)$. One of them (employment of new workers) is negatively correlated with the period of company size. Statistically significant $(\mathrm{p}<0.05)$ and positively correlated is the characteristic: "introducing IT to manage the company". The survey shows also how respondents assess complexity perception in relation to main field of activity. Four of the selected activities of the superior were found out to be statistically significant $(p<0.05)$. One of them (purchase of new machines and devices) is negatively correlated with the period of main field of activity. Statistically significant $(\mathrm{p}<0.05)$ and positively correlated is the following characteristic: 1 . increasing investment in promotion and advertising, 2. upgrading skills and qualifications of employees and 3. Searching for investors and business partners" (table 5). Further analysis took into account complexity profiles based on Cynefin model. The results are shown in the figure 1.

\section{Figure 1: Perception of complexity in areas of company activity according complexity levels.}

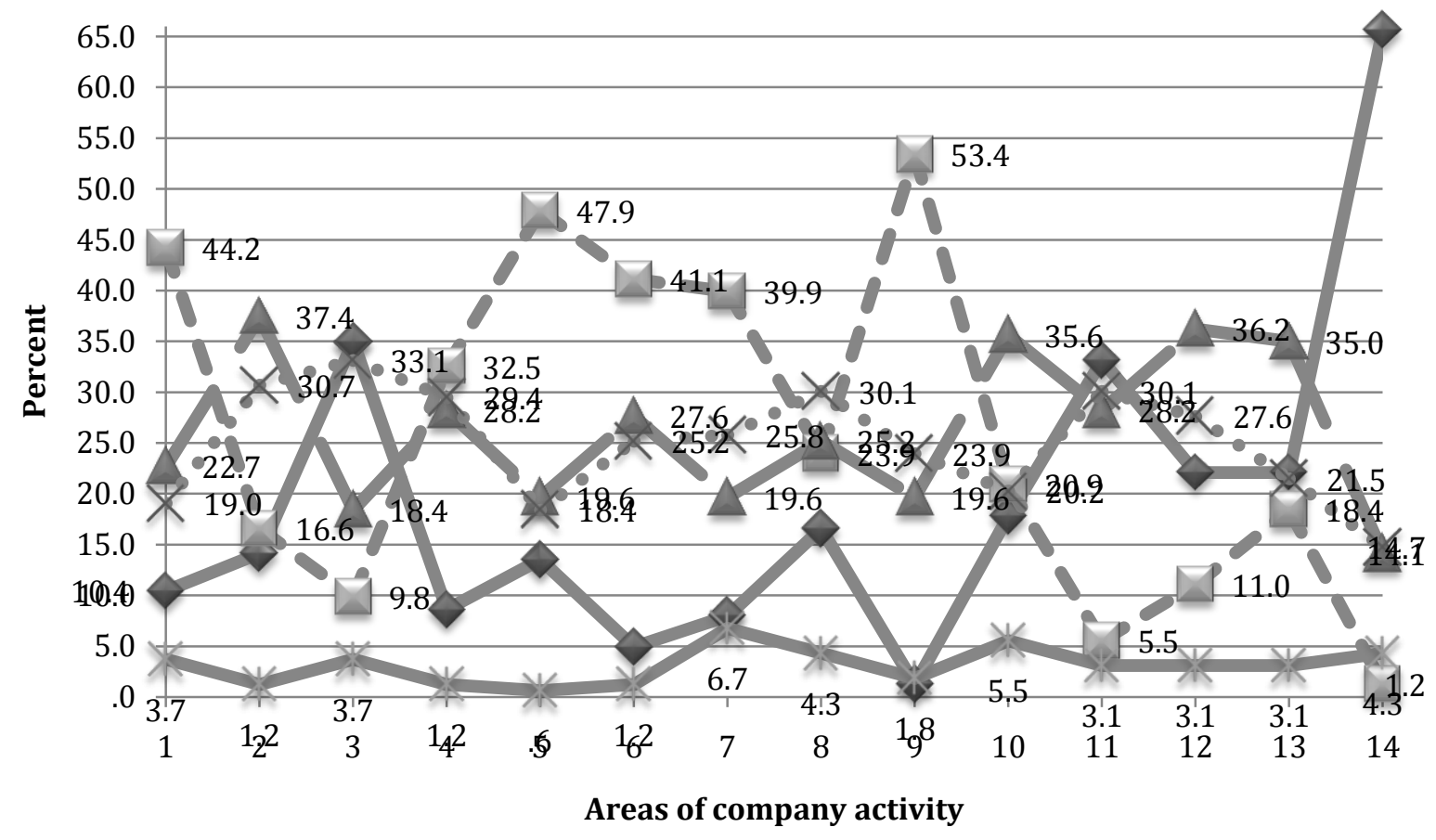

$\neg$ Disorder $-\downarrow$-Simple $\rightarrow$-Complicated $\cdots \Varangle \cdots$ Complex $\rightarrow$ Chaotic

Legend:

1. Searching for new customers and new markets; 2 . increasing investment in promotion and advertising; 3. creating new products and services; 4. co-operation with business organizations; 5.improvement of existing products and services; 6 . purchase of new machines and devices; 7. improvement of quality of products, services and manufacturing; 8. employment of new workers; 9. introducing IT to manage the company; 10. upgrading skills and qualifications of employees; 11. market research; 12. understanding and connecting with other entities; 13. searching for investors and business partners; 14. changes in the scope of business or sector.

Source: own study

Based on 5 complexity levels distinguished in Cynefin model respondents evaluated 14 areas of company. Their indication of allow to formulate the following conclusions. The domain "simple" as areas, where the relationship between cause and effect is for everyone in the organization obvious. They are directly connected, and the processes are predictable and repeatable considered. For main areas in this domain, respondents indicated: introducing IT to manage the company (indicated by more than half of respondents $53,4 \%$ ); improvement of existing products and services $(47,9 \%)$, searching for new customers and new markets $(44,2 \%)$, purchase of new machines and devices $(41,1 \%)$ and improvement of quality of products, 
services and manufacturing (39,9\%). Featured areas are the most common actions in companies, and the processes associated with them usually have standard operating procedures. Second domain "complicated" represent areas, where the relationship between cause and effect requires analysis or other forms of research by experts. The expertise is often needed to understand the relationship between cause and effect and requires investigation. Decision-makers must rely and trust their judgment. For main areas in this domain, respondents indicated: increasing investment in promotion and advertising (37, 4\%), understanding and connecting with other entities (36, 2\%), upgrading skills and qualifications of employees $(35,6 \%)$ and searching for investors and business partners $(35,0 \%)$.

Third domain "complex" represent areas, where cause and effect are not repeated and are detectable only in retrospect. Small changes in the system at the beginning can result in disproportionately large effects. Can be observe patterns of phenomena, but cannot predict their effect. These patterns depend on the interaction between components. For main areas in this domain, respondents indicated: creating new products and services $(33,1 \%)$ and employment of new workers $(30,1 \%)$. Next domain "chaotic" as areas, where the relationship between cause and effect is completely unpredictable. Processes are often sudden, unexpected course. Accompanied by a high-voltage atmosphere. The aim is to transform the chaotic situation at the complex. Indications of respondents in this domain wouldn't exceed 7 percent. For main area in this domain, respondents indicated improvement of quality of products, services and manufacturing (6,7\%). Last domain "disorder" as areas, where lack of information and understanding of the situation impossible to decide on their classification into one of the other domains. For such areas respondents considered: changes in the scope of business or sector (indicated by $2 / 3$ respondents - 65,6\%), creating new products and services $(35 \%)$ and market research $(33,1 \%)$.

\section{Conclusion}

Complexity is a unique problem facing modern companies. Although complexity is a characteristic of modern organization management which obviously influences important decisions, complexity as such is often taken intuitively or from previous experiences. Managing increasing complexity in SMEs is absolutely necessary to companies to compete better in global market. In order to manage complexity effectively and efficiently, it is recommended that complexity has to be defined, measured, analyzed, reduced and avoided. But the first step must be to recognize the complexity of the processes undertaken in the company. This study presents an attempt to identify of complexity levels of business areas by Cynefin model assumptions.

\section{References}

Faisal, A., Rub, A. \& Ayman, I. A. (2012). A business process modeling-based approach to investigate complex processes: Software development case study. Business Process Management Journal, 18(1), 122- 137.

Gorzeń-Mitka, I., Okręglicka, M. \& Lemańska-Majdzik, A. (2015). Complexity management in enterprise sample reflection on interpretation, MEKON 2015. The CD of Participants' Reviewed Papers from 17th International Conference MEKON 2015, Faculty of Economics, VŠB - Technical University of Ostrava, s.652-660.

Gorzeń-Mitka, I. \& Okręglicka, M. (2014). Improving Decision Making in Complexity Environment. Procedia Economics and Finance, 16, 402-409. ISSN 2212-5671

Kurtz, C. F. \& Snowden, D. J. (2003).The new dynamics of strategy: Sense-making in a complex and complicated world. IBM Systems Journal, 42(3).

Lemańska-Majdzik, A. (2009). Czynniki sukcesu firm powstałych w wyniku samozatrudnienia, Sekcja Wydawnictwa Wydziału Zarządzania Politechniki Częstochowskiej, Częstochowa, 2009. ISBN 97883-61118-13-8

McLeod, J. \& Childs, S. (2013). The Cynefin framework: A tool for analyzing qualitative data in information science? Library \& Information Science Research, 35, 299-309.

O'Neill, L. J. (2004). Faith and decision-making in the Bush presidency: The God elephant in the middle of America's living room. Emergence: Complexity and Organization, 6(1/2), 149-156 Available at http:// mergentpublications.com/eco/ECO_other/Issue_6_1-2_20_FM.pdf. 
Shepherd, R., Barker, G., French, S., Hart, A., Maule, J. \& Cassidy, A. (2006). Managing Food Chain Risks: Integrating Technical and Stakeholder Perspectives on Uncertainty. Journal of Agricultural Economics, 57(2), 313-327.

Sipa, M. (2013). Wyzwania globalne i lokalne a proces umiędzynarodowienia małych i średnich przedsiębiorstw [in:] Wyzwania globalne i lokalne zarządzania podmiotami gospodarczymi, (ed.) M.Sipa, SekcjaWydawnicza WZ Politechniki Częstochowskiej, Częstochowa, 2013. ISBN 978-83-7193571-8.

Skibiński, A. (2014). Edukacja jako czynnik determinujący aktywność ekonomiczną ludności a procesy demograficzne na przykładzie województwa śląskiego [in:] Rynek pracy i polityka społeczna w XXI wieku. Aktualne problemy. [Ed.]. Lucyna Machol-Zajda, Cecylia Sadowska-Snarska. Wyd. Instytut Pracy i Spraw Socjalnych w Warszawie; Wydział Ekonomii i Zarządzania Uniwersytetu w Białymstoku 2014, pp. 36-46.

Snowden, D. (2002). Complex Acts of Knowing: Paradox and Descriptive Self Awareness. Journal of Knowledge Management, 6(2), 100-111.

Snowden, D. (2010). The origins of Cynefin, Part 1-7 Available at http://cognitive-edge.com/blog/entry/3505/part--one--origins--of--cynefin.

Snowden, D. \& Boone, M. E. (2007). A Leader's Framework for Decision Making, Harvard Business Review, November 2007, pp. 69-76.

Wieczorek-Kosmala, M. \& Gorzeń-Mitka, I. (2013). Some Remarks on the Proper Understanding of Risk Perception, StudiaEkonomiczne. Zeszyty Naukowe Wydziałowe Uniwersytetu Ekonomicznego w Katowicach, 127, 9-22. 